\title{
CORRUPTION: PROFILE OF POLITICAL COMPANIES IN ROMANIA
}

\author{
Daniela PIRVU
}

The subject of the paper is related to the tainting of the public contract award process and the consequences generated by it: corruption in public procurement, which is a major problem of the Romanian economy, recognised and pointed out both at the national and at the European level. The study provides empirical evidence that between 2009-2013 there were many companies that repeatedly win public procurement contracts and do business only (or almost only) with the local and central authorities (contracting authorities who represent the interests of political parties). At the theoretical level, the profile of these companies, called political companies, is identified.

Keywords: contracting authorities, corruption, political companies, profile, public procurement, work contracts, Romania

JEL classification indices: H40, M13, O10

\section{INTRODUCTION}

In the European Union, the expenditures incurred in the public sector for the procurement of goods, services and works amount to almost 2,500 billion euros (European Commission 2014a). The largest part of these contracts must observe certain common public procurement procedures in all member states.

Pirvu Daniela, Assistant Professor at University of Pitesti, Faculty of Economic Sciences, Romania.E-mail: ddanapirvu@yahoo.com 
Competition for the award of public procurement contracts is high. The foundation of the relevant legislation aims at ensuring the free movement of goods and services within the common market. For this reason, the award of the public procurement contracts must be made based on the following principles: non-discrimination, equal treatment, transparency and proportionality, and correlation between the necessity, the object, and the requirements of the public procurement contract.

The competitive public procurement procedures do not exclude the possibility of the emergence of corruption (Burguet - Che 2004; Lambert-Mogiliansky - Sonin 2006). Over time, the media has indicated the existence of companies that win public procurement contracts suspiciously often. These companies sponsor political parties, or have direct or indirect connections with politicians. The aspects related to the political connections and the allocation of procurement contracts have been studied in the literature (Hellman et al. 2000; Compte et al. 2005; Hyytinen et al. 2009; Coviello - Gagliarducci 2010; Goldman et al. 2013). It was also shown that electoral competition represents a cause of corruption in public procurement (Frøystad et al. 2010). Sensational cases of corruption in public procurements, manifested at the political level, have been reported in many European Union (EU) member states, and through the first anti-corruption report published by the European Commission in February 2014, corruption in public procurements was recognised as an issue at the EU level.

Specialists' concerns relating to corruption in public procurements are generated by the fact that the process of awarding public procurement contracts provides a number of opportunities for developing inappropriate behaviours, one part of which is susceptible of being regarded as acts of corruption. The problem exists outside the EU, too. Several international bodies have developed guidelines and codes of ethics with the purpose of preventing, identifying, and applying certain measures to combat corruption in the process of awarding public procurement contracts (OECD 2007a, 2007b; United Nations Office for Project Services 2011; United Nations Office on Drugs and Crime 2013).

The studies carried out so far prove that the tainting of competition in the award of public procurement contracts is a phenomenon that affects large segments of the public administration (Søreide 2002); a phenomenon which is manifested at the level of certain EU member states, despite the existence of Community legislation on public procurement (OECD 2010; Directorate General for Internal Policies 2013).

The tainting of competition in the award of public procurement contracts has many direct and indirect effects. Direct costs are related to social inefficiency, cost overruns, implementation delays, and efficiency loss, including lower quality and questionable usefulness (Auriol 2006; Coppier - Piga 2006; Wensink - Maarten 
de Vets 2013; Dastidar - Mukherjee 2014). In 2014, Hessami published a theoretical model indicating the proportional increase of countries' corruption indicators and the shares of rent-creating public spending in government budgets.

Public procurements are an important source of corruption in Romania as well. While public procurement contracts account for approximately $25 \%$ of the GDP of Romania (European Commission 2012), and the average EU level is below 20\%, the interest of the firms in business with the state is very high. The misuse of public tenders is a frequent practice and results in the emergence of political companies companies that repeatedly win public procurement contracts and do business only (or almost only) with the state: like elsewhere, there companies and/or their owners sponsor political parties or have personal connections with politicians representing public authorities. The companies surviving almost exclusively due to contracts with the state are either directly owned by politicians or belong to politicallycontrolled people. In the Romanian media, their name is "family companies".

The objectives of this study are: (a) the introduction of a new concept in the "corruption dictionary", namely that of "political companies"; (b) empirical research on the hypothesis according to which political companies are a reality of the Romanian public procurement market; (c) identifying the profile of political companies in Romania.

\section{CORRUPTION IN PUBLIC PROCUREMENTS IN ROMANIA}

There are various tricks of tainting competition: (a) formulating certain qualification and/or selection criteria that favour a certain company; (b) providing confidential information (including about competitors' offers) to one firm only; (c) formulating restrictive criteria that limit the participation of others; (d) mutual understanding between the favoured company and the contracting authority by which the initial offer includes low prices, but the final price of the contract is increased by concluding annexes for various "unforeseeable" works; (e) selective transmission of the tender call to certain companies; (f) misuse of governmental declared state of emergency (e.g. during floods) with the hidden purpose of negotiating the public procurement contract with only one firm, etc.

According to the information supplied by the National Authority for the Regulation of Public Procurements (a public institution, subordinated to the Government, with functions of regulating, monitoring, surveying, and controlling the public procurement market), the main violations/incompliance are: (a) violating the publicity rules by the late submission for the awarding publication notices; (b) breaching the operation principles of the public procurement system by imposing restrictive qualification requirements and/or requesting qualification requirements for sub- 
contractors, failure to submit for publication the decision to cancel the award procedure and failure to observe deadlines provided for the submission of answers to the requests for clarifications; (c) applying the negotiation procedure, without fulfilling the conditions provided by the law; (d) incorrect application, within the assessment process, of the criteria set in the award documentation; (e) concluding contracts with a value exceeding the threshold set by the law, by direct procurement; (f) documents missing from the public procurement file; (g) incomplete communications on the result of the public procurement procedure.

According to the National Anticorruption Directorate (NAD), the warning signals concerning fraud and/or corruption in the public procurement processes can be seen in:

- The stage of preparation and publication (vague technical specifications, very detailed specifications; long decision-making circuits; requests for information immediately before or after the publication of the call for tender);

- The submission of the documentation (small number of bidding offers; missing documents; short deadlines; "perfect offers");

- Assessment and negotiation (the same staff performs all the assessments; price figures or errors corrected by hand; major discrepancies between the initial and the final scores given by assessors; an abnormal distribution of the price);

- The implementation (copies of invoices; forged quality certificates; frequent staff changes; the use of many amendments to contracts or closed tenders; significant changes in prices compared to the prices initially offered; unfinished projects).

The frauds discovered by NAD indicated, among others, the following patterns: (a) the procurement of low-quality, useless, or very expensive products; (b) payments made for unfinished constructions or incomplete works; (c) payments made for undelivered goods or non-provided services.

The problem of corruption in public procurement in Romania is closely related to the practices that characterise the political environment. Political parties receive annual subsidies from the public budget and through donations. Any donation exceeding a certain limit is confiscated and returned to the state budget (Law 334 of 17 July 2006). However, the real cost of election campaigns far exceeds this limit and this is why political parties are tempted to accept unrecorded and undeclared donations.

Several former ministers investigated for acts of corruption in public procurement stated that they financed their political parties in order to facilitate their political support and to keep their public function. They confirmed of that all politi- 
cians who have access to public functions paid significant amounts of money for this purpose. Moreover, the managers of the companies involved in the respective public procurement proceedings stated that they had paid "fees", set as percentage from the value of the public procurement contracts won, in exchange for the support of politicians. These amounts went into the accounts of political parties.

\section{METHODOLOGY}

Our study is based on the assumption that the misuse of public procurement procedures is more frequent in the case of the contracting authorities where the political parties are present: the central and local public administration.

Another working assumption is that companies which frequently win public procurement contracts are companies controlled by politicians. We will call them political companies. The existence of these companies revolves around the public budget. These companies should be given a certain distinct name in the specialised literature, in order to be customised in the business environment, with the purpose of simplifying the exposure about them in future research. Political companies have a low number of customers because they are "subscribed" to the public procurement contracts awarded by certain contracting authorities. Political companies cover certain geographical areas, politically dominated by a certain party.

The first stage of research consisted of creating a database comprising observations collected from work contract award notices submitted for publication in the Supplement to the Official Journal of the European Union (SOJ), during 2009-2013. The option for the analysis of the work contract award notices submitted for publication in the SOJ is determined by the following aspects:

- factors that influence the opportunities for corruption (Heggstad et al. 2010): the size of the contract (the larger the contract, the bigger the bribe) and the sector involved (some sectors are more prone to corruption than others, such as construction, oil and gas, property development, and manufacturing). The contracting authorities in Romania have the obligation to publish the calls for tenders/award notices in the SOJ if the estimated work contract value is higher than or equal to the RON equivalent of the amount of 5 million euros;

- due to the lack of all filters/rules for entering data into the Electronic System of Public Procurement (the communication platform used in Romania), data are erroneously entered by the contracting authorities. Consequently, in my opinion, Tenders Electronic Daily (TED, the online version of the SOJ, dedicated to European public procurement) provides a much more reliable base for the collection of data. 
Table 1. Our database

\begin{tabular}{|l|l|c|c|c|c|}
\hline \multicolumn{2}{|l|}{ Type of contract } & $\begin{array}{c}\text { Utilities } \\
\text { works }\end{array}$ & $\begin{array}{c}\text { Building con- } \\
\text { struction and } \\
\text { other works }\end{array}$ & $\begin{array}{c}\text { Transport infra- } \\
\text { structure works }\end{array}$ & Total \\
\hline 2009 & Number & 108 & 82 & 92 & 282 \\
\hline & Value (mill. euros) & 641 & 657 & 1,388 & 2,686 \\
\hline 2010 & Number & 101 & 94 & 103 & 298 \\
\hline & Value (mill. euros) & 961 & 548 & 1,199 & 2,707 \\
\hline 2011 & Number & 129 & 137 & 156 & 422 \\
\hline & Value (mill. euros) & 805 & 1,213 & 3,779 & 5,797 \\
\hline 2012 & Number & 133 & 135 & 80 & 348 \\
\hline & Value (mill. euros) & 768 & 1,148 & 2,771 & 4,686 \\
\hline 2013 & Number & 73 & 144 & 76 & 293 \\
\hline & Value (mill. euros) & 510 & 1,542 & 1,615 & 3,667 \\
\hline \multicolumn{2}{l|}{ Total - number } & 592 & 544 & 507 & 1643 \\
\hline \multicolumn{2}{l}{ Total - value (mill. euros) } & 3,684 & 5,107 & 10,751 & 19,542 \\
\hline
\end{tabular}

Source: Author's calculations.

The total number of the observations was 1,643 , broken down by years and the type of works contract, as shown in Table 1.

The first statistics concerning the public procurement market in Romania began to be collected in 2012. At that time, it had a value of 12.5 bn euros, of which work contracts had a value of 6.7 bn euros (National Authority for the Regulation and Monitoring of Public Procurements 2013). Consequently, the number of observations in the database used in the study (the value of the work contracts published in the SOJ) accounts for approximately $70 \%$ of the total value of the work contracts awarded by the contracting authorities in Romania and is sufficient to provide the validity of the conclusions.

The announcements concerning work contracts published in the SOJ provided the information concerning the type of work contract (utilities works, transport infrastructure works, building construction, and other works), the value of the contract, the contracting year, the type of public contracting authority (central authority, local authority, public institution, and public company), the type of firms (single Romanian firms, single foreign firms, consortium of Romanian firms, consortium of foreign companies, consortium of firms) and the name of the firms (the name of the consortium leader). The public contracting authorities were divided into four categories:

- Central authorities (ministries, chambers of Parliament, specialised bodies subordinated to the government); 
- Local authorities (prefectures, town halls, local councils, county councils, intercommunity development associations). They are specialised structures through which, as public power authorities, laws are enforced, or, within the limits of the law, public services are provided;

- Public institutions (educational units, medical and sanitary units, libraries, museums, etc.);

- Public companies (legal entities performing economic activities, which are directly or indirectly under the dominating influence of a contracting authority). These are government business enterprises and trading companies in which the state or a local public administration company is a shareholder.

\section{DATA ANALYSIS}

Local authorities contracted the largest number of works, but public companies hold the first place in terms of the value of work contracts (Figure 1).

Most work contracts were awarded to Romanian firms (Figure 2).

As we can see, the public procurement market in Romania is dominated by Romanian firms. Nevertheless, in the years 2012-2013, the number of foreign companies which were awarded work contracts increased. Similarly, the success of consortia was much more frequent at the end of the analysed period compared to its beginning. This shows the internationalisation of the public procurement market (Figure 3).

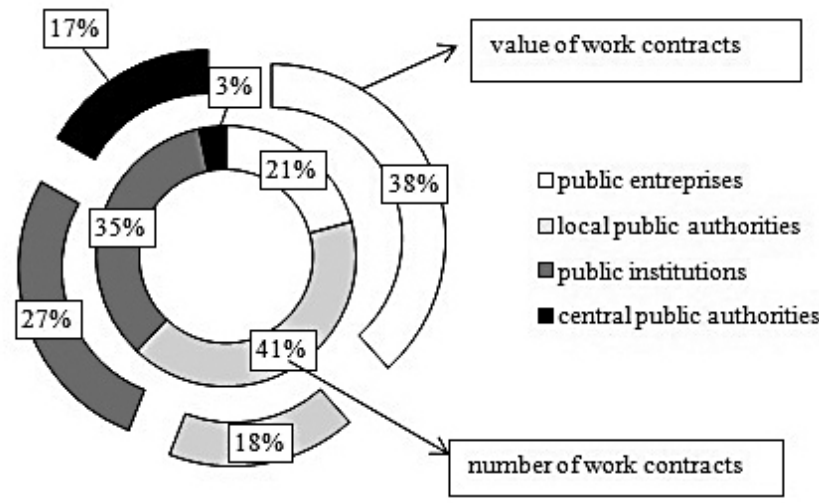

Figure 1. Distribution of work contracts, in terms of number and value, depending on the type of the contracting authorityies

Source: Author's calculations. 


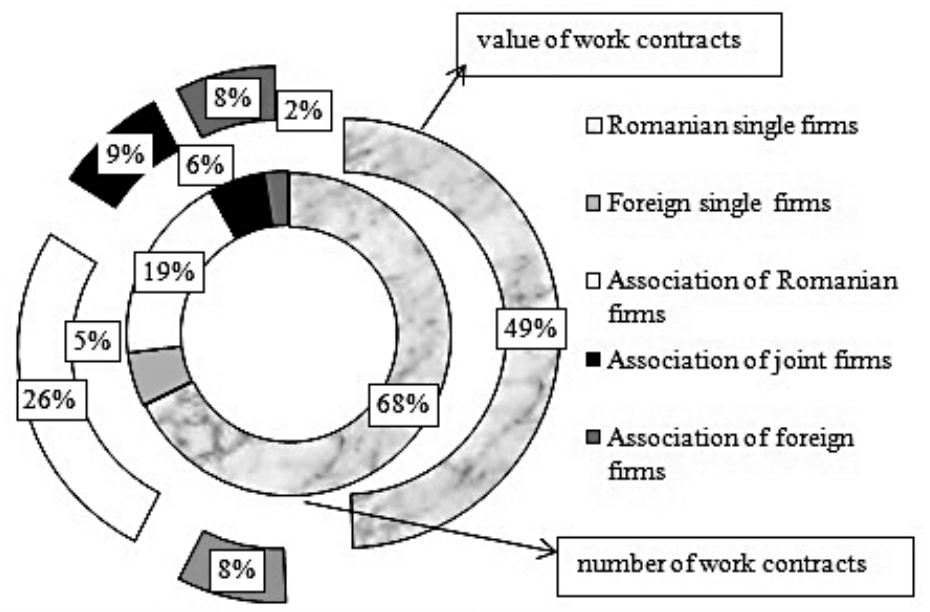

Figure 2. Distribution of work contracts, in terms of number and value, depending on the type of firms

Source: Author's calculations.

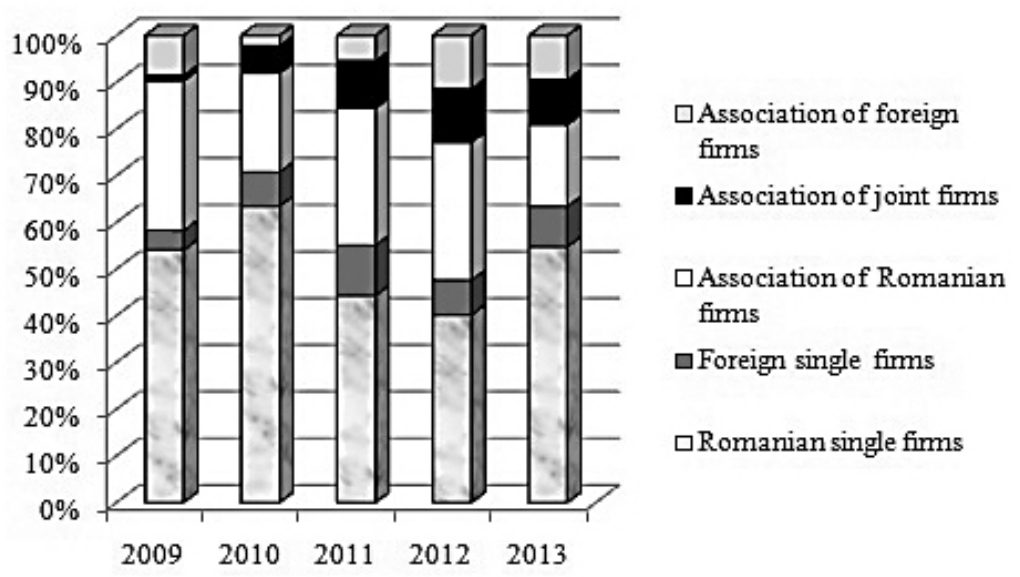

Figure 3. Structure of firms, depending on the value of public work contracts Source: Author's calculations. 
Table 2. The cross tabulation of variables:

the type of the contracting authority and the type of the firms (numbers)

\begin{tabular}{l|c|c|c|c|c}
\hline & $\begin{array}{c}\text { Romanian } \\
\text { single firms }\end{array}$ & $\begin{array}{c}\text { Foreign } \\
\text { single firms }\end{array}$ & $\begin{array}{c}\text { Association } \\
\text { of Romanian } \\
\text { firms }\end{array}$ & $\begin{array}{c}\text { Association } \\
\text { of joint firms }\end{array}$ & $\begin{array}{c}\text { Association } \\
\text { of foreign } \\
\text { firms }\end{array}$ \\
\hline Public enterprises & 225 & 28 & 57 & 22 & 11 \\
\hline Local authorities & 498 & 15 & 133 & 21 & 11 \\
\hline Public institutions & 349 & 45 & 109 & 49 & 15 \\
\hline Central authorities & 41 & 0 & 10 & 1 & 3 \\
\hline
\end{tabular}

Source: Author's calculations.

The trend towards the internationalisation of the public procurement market is a positive signal, because the possibility to misuse the public procurement procedures is lower if the firms are foreign.

The cross-tabulation proves that the variables - the type of the contracting authority and the type of the firm - are correlated (Table 2).

Local and central authorities conclude public contracts with Romanian firms or with their consortia. The bivariate Chi-Square test was used to study the relationship between the variable type of contracting authority and the variable type of the firm. The Pearson Chi-Square Value (882.196) and the "Sig" (.000) value is lower than 0.05 , indicating the existence of a statistical relationship between the variables.

The results of the statistical tests were also confirmed by the quality research of the data. The 1,643 public work contracts were awarded to 583 companies. Therefore, on average, one firm was awarded approximately three public work contracts during the analysed period. The cases when the same firm was awarded more than five work contracts occur especially when the contracting authorities are local or central authorities. All the cases of this type (25 firms which were awarded more than five work contracts by the local or central public authorities) were analysed in order to build a profile of the political companies in Romania. The public work contracts awarded to the 25 firms accounted for approximately $30 \%$ of the total value of the public work contracts. The analysis was based on data in the statistics published by the Ministry of Public Finance on its own website concerning the financial and accounting statements of the respective companies.

In order to analyse the assumption that these companies have common characteristics, representing political parties, I used the hierarchical cluster analysis, the $\mathrm{Z}$ scores method. The formation of a dominating cluster would confirm my assumption.

The variables selected as criteria for grouping were as follows: the average number of employees, the average profit/loss, the average turnover, the average 
value of total capital, the average value of fixed assets and the average value of public work contracts. The cluster method selected was Between-groups linkage and the range of solutions was between 2 and 4 clusters. The results of the cluster analysis are presented in the form of a dendrogram (Figure 4). The names of the firms in the database were replaced with letters from A to W (see Annex 1).

We can note the existence of a voluminous cluster composed of more than $75 \%$ of the companies. The companies in the cluster have on average 200 employees, an annual profit of approximately 1 million euros, a turnover of approximately 20 million euros, total equity capital, and fixed assets lower than 10 million euros. The average value of the public work contracts (mean of the cluster) represent approximately $70 \%$ of the average turnover (mean of the cluster).

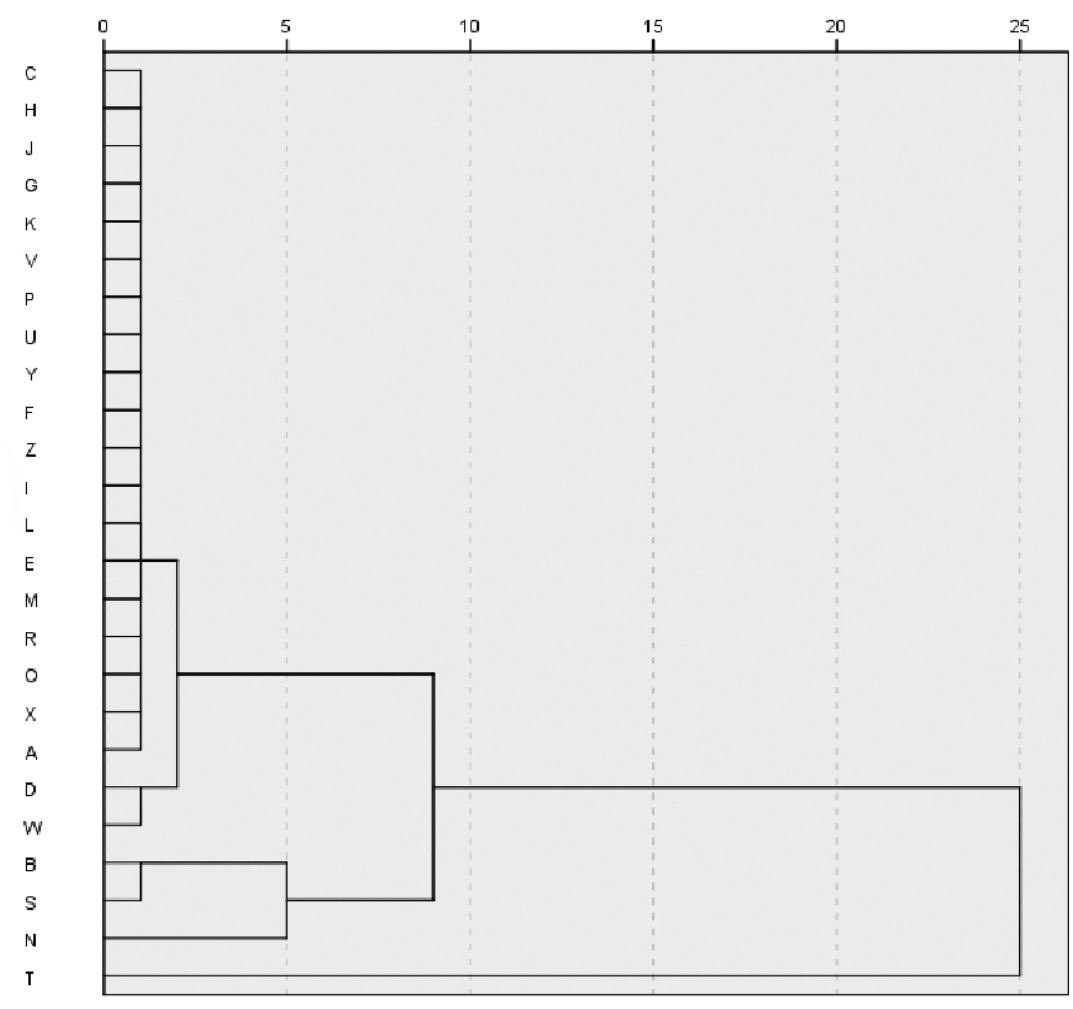

Figure 4. Dendrogram using average linkage (between groups) 


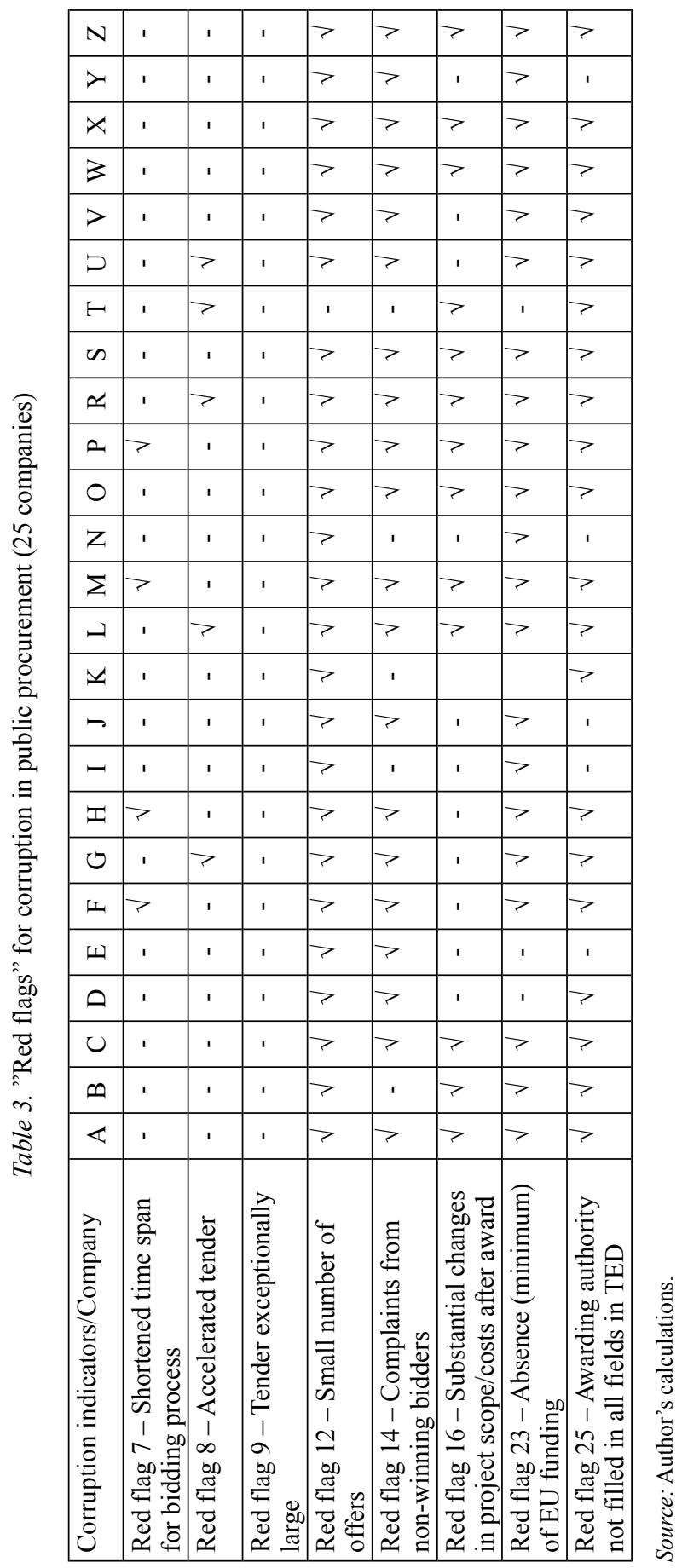


The results of the research were validated by allocating "red flags" (corruption indicators) to companies in the cluster. The red flags were selected according to the criteria defined in the study Identifying and Reducing Corruption in Public Procurement in the EU (2013). For the configuration of the corruption indicators, information collected from the Public Procurement Electronic System (ESPP) was used in relation to work contracts awarded to the respective companies between 2009 and 2013 (Annex 2), and the results were summarised in Table 3. ESPP is an open platform allowing the implementation of a full cycle of electronic public procurement in Romania. In ESPP, all public contract award notices are published, regardless of their value. The ESPP database enables the obtainment of information about the public procurement proceedings used.

Red flags are present in the vast majority of the companies. Corruption indicators (red flags) 12, 14, 23, 25 are the most frequent. Red flag 9 (Tender exceptionally large) does not seem to be an indicator of corruption in Romania. The final value of the contracts awarded to the 25 analysed companies represents $80-90 \%$ of the estimated value. However, it should be mentioned that the incorrect estimation of the value of public procurement contracts by overestimating them is a frequent corruption practice in public procurement.

\section{CONCLUSIONS}

In recent years, the results of the activity of National Anticorruption Directorate (NAD) resulted in many convictions of politicians with public functions (ministers, mayors, chairmen of county councils), demonstrating that there is a worsening of the corruption issue in the public procurement.

The study of NAD press releases from the 2008-2014 period highlighted that the managers of the companies included in the dominating cluster (except 2) are investigated in relation to corruption acts in public procurements. NAD prosecutors mainly showed that the managers of the respective companies bribed politicians and public administration employees in order to win public contracts. In some cases, the money was used to finance election campaigns. This study proves the existence of a distinct category of companies in the Romanian business environment, namely political companies.

The existence of political companies in Romania is highlighted by the following aspects:

- The frequency of awarding a large number of work contracts to the same firm is higher in the case of local and central authorities (which represent 
the interests of political parties) than in the case of other types of contracting authorities;

- A small number of firms (25) completed approximately $20 \%$ of the tenders and $30 \%$ of the value of the work contracts awarded in the 2009-2013 period by the contracting authorities in Romania following the announcements published in the SOJ;

- Almost the entire activity of the above-mentioned companies is ensured by public work contracts.

The analysis of the data in the European public procurement electronic journal, related to work contracts awarded by the contracting authorities in Romania, and the statistics published by the Ministry of Public Finance for the 2009-2013 period highlights the following profile of the political companies in Romania:

- These are medium-sized companies from the point of view of the number of employees;

- Carry out profitable business;

- Most of their turnover is represented by earnings from work contracts awarded by the central and local public authorities;

- The ratio between the average value of the fixed assets and the average value of the total capital is close to 1 ;

- Capital is used efficiently.

Our study proved the existence of a direct relationship between the number of the red flags of a company and the diversity of the clients. Thus, companies with few red flags are characterised by a lower number of contracts awarded by the contracting authorities whose heads belong to the same political party. The membership of the head of the contracting authority in the same political party seems to be a signal of corruption in public procurements, also confirmed by the fact that when certain political parties lost the elections locally, this virtually generated the disappearance of the political company from ESPP. For example, after 2012, when the leaders of the contracting authorities to which company A was subscribed lost the local elections, this company was awarded only one public contract by open tender performed by a joint venture.

Political companies are a signal of the existence of corruption in public procurements. Knowing the profile of the political companies would allow specialists to develop a tool for signalling the risk of the emergence of corruption in public procurement, but this is a further research direction. A future research direction can also be the substantiation of a new red flag: the membership of the manager of the contracting authority in the same political party. 


\section{REFERENCES}

Auriol, E. (2006): Corruption in Procurement and Public Purchase. International Journal of Industrial Organization, 24(5): 867-885.

Burguet, R. - Che, Y. (2004): Competitive Procurement with Corruption. RAND Journal of Economics, 35(1): 50-68.

Compte, O. - Lambert-Mogiliansky, A. - Verdier, T. (2005): Corruption and Competition in Procurement Auctions. RAND Journal of Economics, 36(1): 1-15.

Coppier, R. - Piga, G. (2006): Why do Transparent Public Procurement and Corruption Go Hand in Hand? Rivista di Politica Economica, 96(1): 185-206.

Coviello, D. - Gagliarducci, S. (2010): Building Political Collusion: Evidence from Procurement Auctions. IZA Discussion Papers, 4939. Available at: ftp.iza.org/dp4939.pdf

Dastidar, K.D. - Mukherjee, D. (2014): Corruption in Delegated Public Procurement Auctions. European Journal of Political Economy, 35(C): 122-127.

Directorate General for Internal Policies (2013): Political and Other Forms of Corruption in the Attribution of Public Procurement Contracts and Allocation of EU Funds: Extent of the Phenomenon and Overview of Practices. Bruxelles. Available at: http://www.europarl.europa.eu/ document/activities/cont/201306/20130619ATT68036/20130619ATT68036EN.pdf

European Commission (2014a): EU Anti-corruption Report. Bruxelles. Available at: http:// ec.europa.eu/dgs/home-affairs/e-library/documents/policies/organized-crime-and-human-trafficking/corruption/docs/acr_2014_en.pdf

European Commission (2014b): Public Procurement Indicators. Bruxelles. Available at: http:// ec.europa.eu/internal_market/publicprocurement/docs/modernising_rules/public-procurementindicators-2011_en.pdf

Frøystad, M. - Heggstad, K. - Fjeldstad, O.H. (2010): Linking Procurement and Political Econo$m y$. Study for Department for International Development and the World Bank Institute. Bergen: Chr. Michelsen Institute. Available at: http://www.cmi.no/publications/file/3955-linking-procurement-and-political-economy-a-gui.pdf

Goldman, E. - Rocholl, J. - So, J. (2013): Politically Connected Boards of Directors and the Allocation of Procurement Contracts. Review of Finance, 17(5): 1617-48.

Heggstad, K. - Frøystad, M. - Isaksen, J. (2010): The Basics of Integrity in Procurement. A Guidebook. Commissioned by Department for International Development. Bergen: Chr. Michelsen Institute. Available at: http://www.cmi.no/publications/file/4211-the-basics-of-integrity-in-procurement.pdf

Hellman, J. - Jones, G. - Kaufmann, D. - Schankerman, M. (2000): Measuring Governance, Corruption and State Capture: How Firms and Bureaucrats Shape the Business Environment. World Bank: Policy Research Paper 2312. Available at: http://siteresources.worldbank.org/INTWBIGOVANTCOR/Resources/measure.pdf

Hessami, Z. (2014): Corruption, Public Procurement, and the Budget Composition: Theory and Evidence from OECD Countries. European Journal of Political Economy, 34: 372-389.

Hyytinen, A. - Lundberg, S. - Toivanen, O. (2009): Politics and Procurement: Evidence from Cleaning Contracts. Helsinki Center of Economic Research Discussion Paper, 277. Available at: http://ethesis.helsinki.fi/julkaisut/eri/hecer/disc/277/politics.pdf

Lambert-Mogiliansky, A. - Sonin, K. (2006): Collusive Market Sharing and Corruption in Procurement. Journal of Economics \& Management Strategy, 15(4): 883-908.

Ministry of Public Finance: Tax and Balances Information. Bucharest. Available at: http://www. mfinante.ro/pjuridice.html?pagina $=$ domenii 
National Anticorruption Directorate in Romania (2012 and 2013): Annual Report. Bucharest: National Anticorruption Directorate in Romania. Available at: http://www.pna.ro/obiect2.jsp;jsess ionid=16d2b4dbf00a00550f4ee2234aa6?id=231, http://www.pna.ro/obiect2.jsp;jsessionid=16d 2b4dbf00a00550f4ee2234aa6?id=208

National Authority for Regulating and Monitoring Public Procurement (2013): Study on Public Procurement in 2012. Bucharest: National Public Procurement Authority. Available at: http:// www.anrmap.ro/sites/default/files/comunicate/comunicat-1968.pdf

National Public Procurement Authority (2012): Annual Report. Bucharest. Available at: http:// www.anrmap.ro/sites/default/files/informatii/informatii-2107.pdf

OECD (2007a): Integrity in Public Procurement. Good practice from A to Z. Paris. Available at: www.oecd.org/dataoecd/43/36/38588964.pdf

OECD (2007b): Bribery in Public Procurement. Methods, Actors and Counter-Measures. Paris. Available at: http://www.oecd.org/daf/anti-bribery/anti-briberyconvention/44956834.pdf

OECD (2010): Collusion and Corruption in Public Procurement. Paris. Available at: www.oecd. org/competition/cartels/46235884.pdf

Søreide, T. (2002): Corruption in Public Procurement. Causes, Consequences and Cures. Bergen: Chr. Michelsen Institute. Available at: http://www.cmi.no/publications/2002\%5Crep $\% 5 \mathrm{Cr} 200$ 2-1.pdf

United Nations Office on Drugs and Crime (2013): Guidebook on Anti-Corruption in Public Procurement and the Management of Public Finances. Vienna. Available at: http://www.unodc.org/ documents/corruption/Publications/2013/Guidebook_on_anti-corruption_in_public_procurement_and_the_management_of_public_finances.pdf

United Nations Office for Project Services (2011): Transparency and Public Procurement. Copenhagen. Available at: https://www.ungm.org/Areas/Public/Downloads/ASR_2011_supplement. pdf

Wensink, W. - Maarten de Vet, J. (eds) (2013): Identifying and Reducing Corruption in Public Procurement in the EU. (Development of a Methodology to Estimate the Direct Costs of Corruption and Other Elements for an EU-Evaluation Mechanism in the Area of Anti-Corruption.) Study prepared for the European Commission. Bruxelles. Available at: http://ec.europa.eu/anti_fraud/ documents/anti-fraud-policy/research-and-studies/identifying_reducing_corruption_in_public_procurement_en.pdf 


\section{ANNEX 1}

\begin{tabular}{|c|c|c|c|c|c|c|c|}
\hline 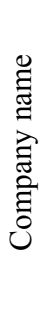 & 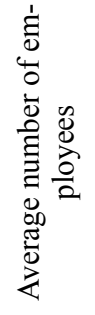 & 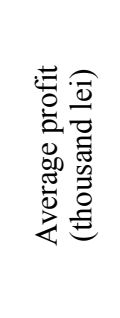 & 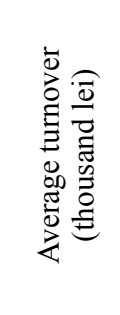 & 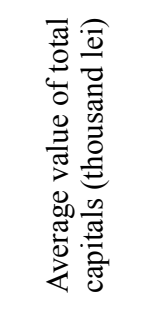 & 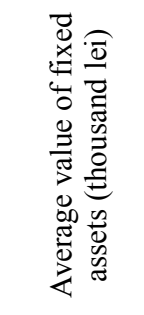 & 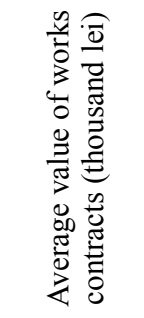 & 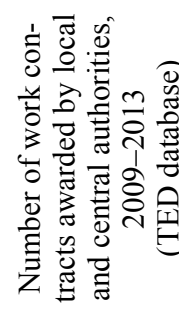 \\
\hline $\mathrm{A}$ & 330 & 19,299 & 225,891 & 75,186 & 61,561 & 57,071 & 30 \\
\hline $\mathrm{B}$ & 1,149 & 51,193 & 43,083 & 314,584 & 323,434 & 602,882 & 10 \\
\hline $\mathrm{C}$ & 350 & 3,443 & 53,607 & 30,571 & 35,476 & 31,178 & 33 \\
\hline $\mathrm{D}$ & 696 & $-13,860$ & 424,228 & 119,137 & 116,520 & 145,645 & 7 \\
\hline $\mathrm{E}$ & 168 & 4,617 & 81,738 & 13,405 & 11,666 & 158,041 & 7 \\
\hline $\mathrm{F}$ & 103 & 5,413 & 28,447 & 21,217 & 8,443 & 41,624 & 8 \\
\hline $\mathrm{G}$ & 215 & 1,547 & 74,794 & 37,329 & 35,809 & 28,013 & 7 \\
\hline $\mathrm{H}$ & 240 & 240 & 52,515 & 377,634 & 41,25 & 33,216 & 5 \\
\hline I & 144 & 1,546 & 26,906 & 5,800 & 11,205 & 55,609 & 5 \\
\hline $\mathrm{J}$ & 182 & 1,250 & 50,999 & 19,816 & 26,962 & 25,297 & 5 \\
\hline $\mathrm{K}$ & 210 & 3,712 & 70,646 & 24,676 & 5,917 & 37,125 & 7 \\
\hline L & 210 & 689 & 25,929 & 9,349 & 7,679 & 13,554 & 5 \\
\hline $\mathrm{M}$ & 489 & 13,882 & 130,968 & 49,503 & 35,116 & 74,906 & 10 \\
\hline $\mathrm{N}$ & 1,322 & 57,510 & 746,546 & 292,868 & 565,768 & $1,220,260$ & 17 \\
\hline $\mathrm{O}$ & 209 & 10,797 & 15,7831 & 62,678 & 48,388 & 84,801 & 10 \\
\hline $\mathrm{P}$ & 158 & 3,582 & 74,266 & 21,694 & 48,696 & 57,323 & 6 \\
\hline $\mathrm{R}$ & 184 & 11,842 & 119,330 & $47,449.3$ & $30,966.5$ & 83,783 & 13 \\
\hline $\mathrm{S}$ & 2,073 & 17,957 & 511,970 & $311,140.7$ & $360,675.2$ & 571,974 & 31 \\
\hline $\mathrm{T}$ & 673 & 7,819 & 172,392 & $49,908.6$ & $31,363.9$ & $1,859,616$ & 12 \\
\hline $\mathrm{U}$ & 60 & 3,113 & 78,111 & $24,043.8$ & $30,195.6$ & 49,402 & 7 \\
\hline $\mathrm{V}$ & 125 & 3,738 & 55,667 & 19,887 & 18,677 & 52,703 & 10 \\
\hline $\mathrm{W}$ & 1,874 & 19,000 & 340,516 & $123,818.7$ & $128,262.8$ & 409,366 & 26 \\
\hline$X$ & 221 & 2,088 & 183,137 & $23,889.1$ & $28,647.3$ & 39,559 & 5 \\
\hline $\mathrm{Y}$ & 217 & 6,057 & 77,011 & $42,976.6$ & $55,544.8$ & 46,233 & 11 \\
\hline $\mathrm{Z}$ & 224 & 1,257 & 35,555 & $9,783.5$ & $9,934.2$ & 32,858 & 6 \\
\hline
\end{tabular}

Notes: Names of the companies are the following: A: Confort SC; B: Constructii Erbasu SC; C: Delta Antrepriza de Constructii si Montaj 93 Ltd; D: Deltacons SC; E: DiferitLtd; F: Drumuri si Poduri Mures Ltd; G: Geiger Transilvania Ltd; H: General Trust Arges Ltd; I: Grup Corint SC; J: Integral SC; K: Iridex Group Constructii Ltd; L: Romconstruct Holding Grup SC; M: Selina Ltd; N: Romstrade Ltd; O: Tancrad Ltd; P: Tehnic Asist Ltd; R: Tehnodomus SC; S: Tehnologica Radion Ltd; T: Tel Drum SC; U: Trans Baco Ltd; V: Transmir Ltd; X: Vega 93 Ltd; Y: Viarom Construct SC; Z: Victor Construct Ltd; W: Recon SC. 
ANNEX 2

\begin{tabular}{|c|c|c|c|c|c|c|c|c|c|c|c|}
\hline \multirow{2}{*}{ 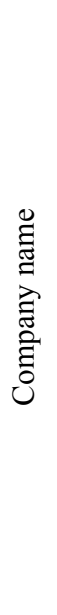 } & \multicolumn{4}{|c|}{ 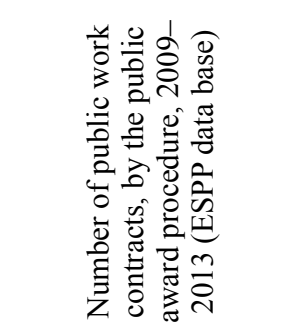 } & \multirow{2}{*}{ 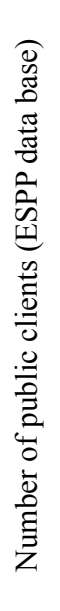 } & \multirow{2}{*}{ 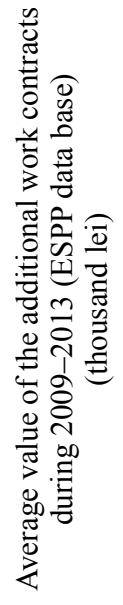 } & \multirow{2}{*}{ 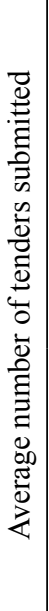 } & \multirow{2}{*}{ 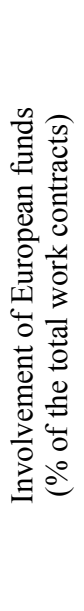 } & \multirow{2}{*}{ 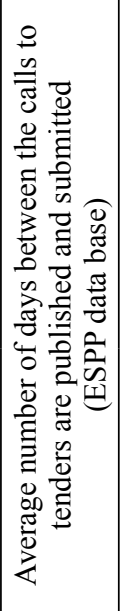 } & \multirow{2}{*}{ 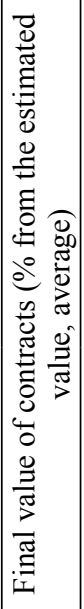 } & \multirow{2}{*}{ 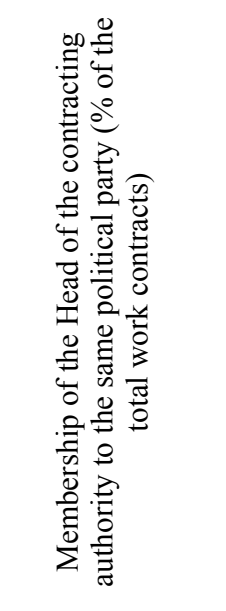 } \\
\hline & 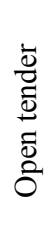 & 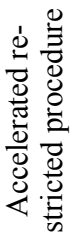 & 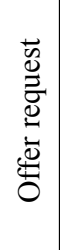 & 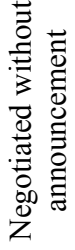 & & & & & & & \\
\hline A & 32 & 0 & 20 & 34 & 8 & 24,514 & 4 & 26 & 28 & 83 & $\begin{array}{c}97 \text { - Liberal } \\
\text { Democratic Party }\end{array}$ \\
\hline B & 9 & 0 & 2 & 11 & 11 & 11,224 & 5 & 20 & 30 & 81 & $\begin{array}{c}71 \text { - Social } \\
\text { Democratic Party }\end{array}$ \\
\hline $\mathrm{C}$ & 9 & 0 & 44 & 10 & 28 & 9,621 & 4 & 19 & 36 & 81 & $\begin{array}{c}90-\text { Liberal } \\
\text { Democratic Party }\end{array}$ \\
\hline $\mathrm{D}$ & 4 & 0 & 1 & 4 & 4 & 29,129 & 2 & 50 & 40 & 90 & $\begin{array}{c}73 \text { - Liberal } \\
\text { Democratic Party }\end{array}$ \\
\hline $\mathrm{E}$ & 6 & 0 & 10 & 2 & 13 & 15,804 & 5 & 40 & 37 & 85 & $\begin{array}{c}50 \text {-Liberal } \\
\text { Democratic Party }\end{array}$ \\
\hline $\mathrm{F}$ & 17 & 0 & 30 & 3 & 12 & 4,995 & 3 & 17 & 26 & 80 & $\begin{array}{c}68 \text { - Democratic } \\
\text { Union of } \\
\text { Hungarians } \\
\text { in Romania } \\
\end{array}$ \\
\hline G & 7 & 5 & 13 & 0 & 12 & 0 & 4 & 18 & 28 & 80 & $\begin{array}{c}51-\text { Social } \\
\text { Democratic Party }\end{array}$ \\
\hline $\mathrm{H}$ & 4 & 0 & 12 & 3 & 7 & 4,982 & 2 & 15 & 27 & 87 & $\begin{array}{c}100-\text { Social } \\
\text { Democratic Party }\end{array}$ \\
\hline I & 4 & 0 & 1 & 0 & 4 & 0 & 5 & 22 & 32 & 91 & Heterogeneous \\
\hline $\mathrm{J}$ & 5 & 0 & 3 & 5 & 6 & 6,324 & 4 & 20 & 30 & 87 & $\begin{array}{c}90-\text { Social } \\
\text { Democratic Party }\end{array}$ \\
\hline $\mathrm{K}$ & 5 & 0 & 2 & 4 & 7 & 7,425 & 3 & 25 & 31 & 82 & $\begin{array}{c}64-\text { Social } \\
\text { Democratic Party }\end{array}$ \\
\hline $\mathrm{L}$ & 5 & 1 & 2 & 7 & 6 & 4,066 & 4 & 18 & 29 & 80 & $\begin{array}{c}70-\text { Social } \\
\text { Democratic Party }\end{array}$ \\
\hline M & 7 & 0 & 19 & 11 & 6 & 29,213 & 3 & 16 & 26 & 84 & $\begin{array}{l}98 \text { - National } \\
\text { Liberal Party }\end{array}$ \\
\hline $\mathrm{N}$ & 9 & 0 & 8 & 5 & 6 & 366,078 & 3 & 20 & 30 & 84 & $\begin{array}{l}60 \text { - National } \\
\text { Liberal Party }\end{array}$ \\
\hline
\end{tabular}




\section{ANNEX 2 CONTINUED}

\begin{tabular}{|c|c|c|c|c|c|c|c|c|c|c|c|}
\hline \multirow{2}{*}{ 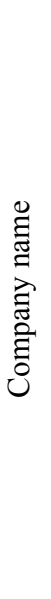 } & \multicolumn{4}{|c|}{ 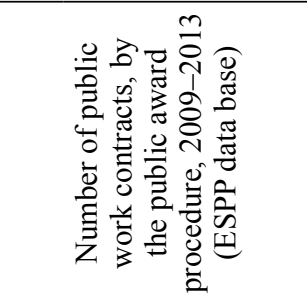 } & \multirow{2}{*}{ 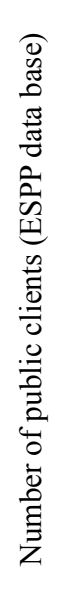 } & \multirow{2}{*}{ 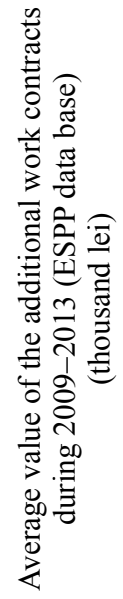 } & \multirow{2}{*}{ 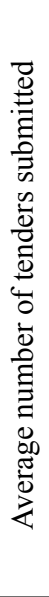 } & \multirow{2}{*}{ 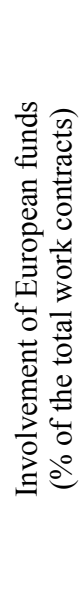 } & \multirow{2}{*}{ 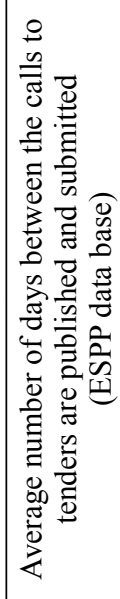 } & \multirow{2}{*}{ 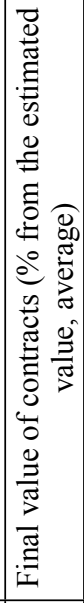 } & \multirow{2}{*}{ 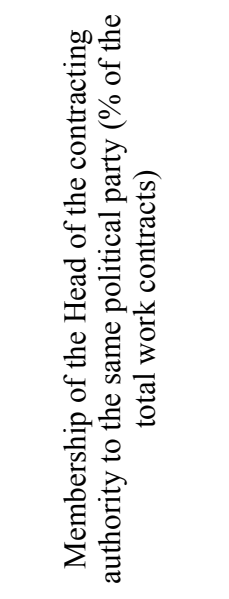 } \\
\hline & 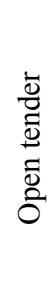 & 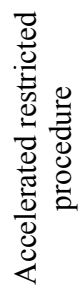 & 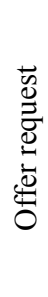 & 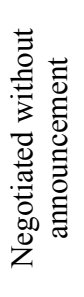 & & & & & & & \\
\hline $\mathrm{O}$ & 10 & 0 & 20 & 10 & 24 & 29,680 & 4 & 18 & 30 & 82 & $\begin{array}{c}89-\text { Social } \\
\text { Democratic Party }\end{array}$ \\
\hline $\mathrm{P}$ & 10 & 0 & 20 & 8 & 14 & 20,636 & 2 & 19 & 26 & 86 & $\begin{array}{l}\text { 95- National } \\
\text { Liberal Party }\end{array}$ \\
\hline $\mathrm{R}$ & 39 & 2 & 38 & 20 & 22 & 41,125 & 4 & 13 & 25 & 82 & $\begin{array}{c}100-\text { Social } \\
\text { Democratic Party }\end{array}$ \\
\hline $\mathrm{S}$ & 8 & 0 & 8 & 12 & 13 & 285,987 & 4 & 20 & 32 & 85 & $\begin{array}{l}82 \text { - National } \\
\text { Liberal Party }\end{array}$ \\
\hline $\mathrm{T}$ & 12 & 1 & 16 & 7 & 16 & 613,673 & 6 & 32 & 28 & 81 & $\begin{array}{c}97-\text { Social } \\
\text { Democratic Party }\end{array}$ \\
\hline $\mathrm{U}$ & 6 & 1 & 9 & 13 & 7 & 24,701 & 3 & 14 & 30 & 80 & $\begin{array}{l}79-\text { National } \\
\text { Liberal Party }\end{array}$ \\
\hline $\mathrm{V}$ & 14 & 0 & 20 & 4 & 6 & 7,905 & 4 & 15 & 27 & 89 & $\begin{array}{c}96-\text { Social } \\
\text { Democratic Party }\end{array}$ \\
\hline W & 13 & 0 & 20 & 7 & 11 & 81,873 & 3 & 17 & 28 & 82 & $\begin{array}{c}98-\text { Social } \\
\text { Democratic Party }\end{array}$ \\
\hline $\mathrm{X}$ & 11 & 0 & 2 & 7 & 8 & 870,298 & 3 & 16 & 30 & 85 & $\begin{array}{c}85 \text { - Liberal } \\
\text { Democratic Party }\end{array}$ \\
\hline $\mathrm{Y}$ & 5 & 0 & 4 & 1 & 8 & 231,165 & 5 & 30 & 30 & 84 & $\begin{array}{l}53-\text { National } \\
\text { Liberal Party }\end{array}$ \\
\hline $\mathrm{Z}$ & 10 & 0 & 17 & 10 & 15 & 131,432 & 4 & 14 & 26 & 80 & $\begin{array}{c}92-\text { Social } \\
\text { Democratic Party }\end{array}$ \\
\hline
\end{tabular}

